\title{
Environmental impact of phosphate mining and beneficiation: review
}

\begin{abstract}
Although the subject of mining and its environmental impacts are very wide to be covered in this review, concerns about the impact of phosphate mining and processing typically emphasis on its potential effects on water pollution, air pollution, and human health were accessed. We reviewed published information at different stages of mining; current mines, closed old mines and reclaimed mines and at different complexity of mining; surface mining, underground mining and sea-bed phosphorite mining. Information was analyzed to understand the association of toxic metals and radioactive elements in the phosphate rocks and to trace the transfer pathways of toxic metals and radioactive elements from the phosphate rocks to the environment. According to the reviewed results the major environmental impacts of phosphate mining and processing on the water resources were: impacts on the hydrology by phosphate industry water usage and landscape changes, and impacts on water quality by discharges of industry wastewater into the waterways. Dust was a common air quality problem throughout all mining activities; fluoride emissions and radon gas emission were also serious problems. Toxic metals and radioactive elements of significant human health problems were $\mathrm{Pb}, \mathrm{Cd}, \mathrm{Hg}, \mathrm{Cr}, \mathrm{As}$, $\mathrm{U}$ Th and $\mathrm{Ra}$. Most researches agreed that ${ }^{226} \mathrm{Ra}$ is considered as one of the most toxic radionuclide. The nuclide is of further importance as the parent nuclide of the gaseous ${ }^{222} \mathrm{Rn}$ which, along with its solid decay products, constitutes a significant source of radiation exposure. Scientific researches on mine water drainage and phosphate mining relationship may help to understand the environmental impacts associated with water resource and water quality.
\end{abstract}

Keywords: phosphate mining, environmental impact, toxic metals, radionuclide, water quality
Volume 2 Issue 4 - 2018

\author{
Gebrehiwet Reta, ${ }^{1,2}$ Xiaohua Dong, ${ }^{1,2}$ \\ Zhonghua $\mathrm{Li}^{3}{ }^{3}$ Bob Su, ${ }^{4,1}$ Xiaonong Hu, ${ }^{5,1}$ \\ Huijuan Bo, ${ }^{1,2}$ Dan Yu, ${ }^{1,2}$ Hao Wan, ${ }^{1,2}$ Ji Liu, ${ }^{1,2}$ \\ Yinghai Li, ${ }^{1,2}$ Gang Xu, ${ }^{1,2}$ Kai Wang, ${ }^{6}$ Shijin \\ $\mathrm{Xu}^{6}$ \\ 'College of Hydraulic \& Environmental Engineering, China Three \\ Gorges University, China \\ ${ }^{2}$ Hubei Provincial Collaborative Innovation Center for Water \\ Security, China \\ ${ }^{3}$ Comprehensive Law Enforcement Bureau for Protection of \\ Water Resources in the Huangbaihe River Basin, China \\ ${ }^{4}$ Department of Water resources, University of Twente, \\ Netherlands \\ ${ }^{5}$ Institute of Groundwater and Earth Sciences, Jinan University, \\ China \\ ${ }^{6} \mathrm{Hydrologic}$ Bureau of Huaihe River Commission, China
}

\begin{abstract}
Correspondence: Xiaohua Dong, College of Hydraulic \& Environmental Engineering, China Three Gorges University, Yichang, 443002, China, Tel +86-139-7260-49I7,
\end{abstract} Email xhdong@ctgu.edu.cn

Received: June 28, 2018 | Published: July 05, 2018

\section{Introduction}

Phosphorus is common within geological materials. The average continental crust contains $0.27 \% \mathrm{P}_{2} \mathrm{O}_{5}{ }^{1}$ Phosphorus is the primary resources to produce fertilizer and phosphorous-based products. ${ }^{2}$ Phosphorus is neither substitutable nor recyclable, therefore, the total demand must be provided through the mining, beneficiation and chemical processing of phosphate ores. The key to understanding the association between environmental pollution and phosphate rocks lies in appreciating the mining and processing effect of phosphate ores. Phosphorus is normally produced by mining and beneficiation of Phosphate ores. ${ }^{3}$ Mines produce large amounts of waste including toxic metals and radioactive elements. ${ }^{4}$ The mining and beneficiation process results in the majority of these hazardous elements being lost either to waste disposal or to the environment, mainly soil, water, atmosphere and human food chain. ${ }^{5,6}$ Apatite is the dominant mineral in phosphate ores. It may occur as carbonate-fluorapatite $\left[\mathrm{Ca}_{5}\left(\mathrm{PO}_{4}, \mathrm{CO}_{3}\right)_{3}(\mathrm{OH}, \mathrm{F})\right]$ in sedimentary rocks and as hydroxyl-fluorapatite $\left[\mathrm{Ca}_{5}(\mathrm{PO} 4)_{3}(\mathrm{OH})\right]$ in igneous rocks. Apatite is commonly very insoluble in its original state as extracted from the earth and is practically unavailable as a plant phosphorus source. ${ }^{7}$ For this reason, drastic chemical processing with strong acids (such as Sulfuric acid, phosphoric or nitric acids) is necessary to produce soluble phosphate products. By virtue of its chemical behavior, apatite is generally associated with fluoride, which is a potential risk for human health. During the current decade there is a rising concerns about the environmental impacts of the phosphate mining industries. Most of the impacts are being reflected in the form of changes to local hydrology, water contamination, water consumption, air pollution and human risk. ${ }^{89}$ Environmental impact of phosphate mining and beneficiation which is directly or indirectly related to water resources is the subject of this review. The review result will provide a summarized update to the undergoing researches in this field.

\section{Material and methods}

We follow the Systematic Literature Review (SLR) guideline proposed by Okoli \& Schabram ${ }^{10}$ During the reviewing, only published information was used, there was no time period limit for the literatures used. Literatures from different locations of the world, at different level and complexity of phosphate mining (surface, underground or sea-bed phosphorite mining) were accessed; large-scale phosphate mines were taken as a complete mining and processing documentation for this study; closed old mines and reclaimed mines were considered as an important references to reconstruct the historical consequence of the mining on the environment. This review is structured into result and discussion: the result part was used to extract relevant information about phosphate rock basics, mining and beneficiation, the association of toxic metals and radioactive elements in the phosphate rocks and the transfer pathways of these hazardous elements from the phosphate rocks to the environment. The discussion part was mainly concerned on the environmental impact of phosphate mining and processing with main emphasis on water pollution, air pollution and human risks. 


\section{Result}

\section{Phosphate rocks, mining and beneficiation}

\section{Phosphate rocks}

Phosphate rocks can be mined from three main deposits, ${ }^{11,12}$ the dominant deposits are sedimentary source $(75 \%)$, Igneous sources
$(15-20 \%)$ and animal such as bird and bat guano source (2-3\%). There are about 200 verities of phosphate minerals of which the minable ones are the apatite groups. ${ }^{1,13-15}$ (Table 1). The Apatite group can be expressed as: $\mathrm{Y}_{5}\left(\mathrm{ZO}_{4}\right)_{3}(\mathrm{OH}, \mathrm{F}, \mathrm{Cl})$ when $\mathrm{Y}=\mathrm{Ca}$ and $\mathrm{Z}=\mathrm{P}$. However in natural form apatite structure can be replaced by several elements: $\mathrm{Y}$ can be replace by $\mathrm{Sr}, \mathrm{Pb}, \mathrm{Ba}, \mathrm{Na}, \mathrm{Cd}, \mathrm{Mg}, \mathrm{Mn}, \mathrm{Fe}$ and $\mathrm{Z}$ replace by $\mathrm{PO}_{4}, \mathrm{Si}, \mathrm{SO}_{4}, \mathrm{As}, \mathrm{CO}_{3}, \mathrm{~V}$, and others. ${ }^{16,17}$

Table I Main varieties of apatite and their formulae from ${ }^{59}$

\begin{tabular}{lll}
\hline Variety formula & Variety formula & Major category \\
\hline Francolite & $\mathrm{Ca}_{10}-\mathrm{x}-\mathrm{y} \mathrm{Nax} \mathrm{Mgy}\left(\mathrm{PO}_{4}\right)_{6}-\mathrm{Z}\left(\mathrm{CO}_{3}\right) \mathrm{zF} \mathrm{F}_{2} \mathrm{~F} .4 \mathrm{z}$ & Sedimentary \\
Hydroxyl-fluor-carbonate apatites & $\mathrm{Ca}_{10}\left(\mathrm{PO}_{4}, \mathrm{CO}_{3}\right)_{6}(\mathrm{OH}, \mathrm{F})_{2}$ & Sedimentary \\
Dahllite & $3 \mathrm{Ca}_{3}(\mathrm{PO})_{2} \cdot \mathrm{CaCO}_{3} \cdot$ & Sedimentary \\
Collophane & $3 \mathrm{Ca}_{3}(\mathrm{PO})_{2} \cdot \mathrm{nCa}\left(\mathrm{CO}_{3}, \mathrm{~F}_{2}, \mathrm{O}\right) \times \mathrm{H}_{2} \mathrm{O}$ & Sedimentary \\
Fluor-apatite & $\mathrm{Ca}_{10}(\mathrm{PO})_{6} \mathrm{~F}_{2}$ & Igneous \\
Hydroxyl apatite & $\mathrm{Ca}_{10}(\mathrm{PO})_{6},(\mathrm{OH})_{2}$ & Igneous \\
Chlorapatite, & $\mathrm{Ca}_{10}(\mathrm{PO} 4)_{6} \mathrm{Cl}_{2}$ & Igneous \\
Carbonate-hydroxy-apatite & $\mathrm{Ca}_{10}\left(\mathrm{PO}, \mathrm{CO}_{3}\right)_{6}(\mathrm{OH})_{2}$ & Biogenic \\
\hline
\end{tabular}

\section{Mining and beneficiation}

There are two types phosphate mining methods based on the depth and deposit geometry, the surface (strip) mining method (for deposit up to $100 \mathrm{~m}$ ) and the underground mining method (for deposit greater than $100 \mathrm{~m}$ ). However surface mining such as strip mining can affect a wide area than underground mining does, therefore, can be an important factor of environmental degradation. ${ }^{18}$ Beneficiation is the process of removing the unnecessary minerals, which is used to increase the grade of mining product (concentrate). Phosphate ores can be beneficiated using one or a combination of different methods. ${ }^{19-21}$ The most common ones are: flotation, crushing, desliming, separation, grinding and washing (Figure 1).

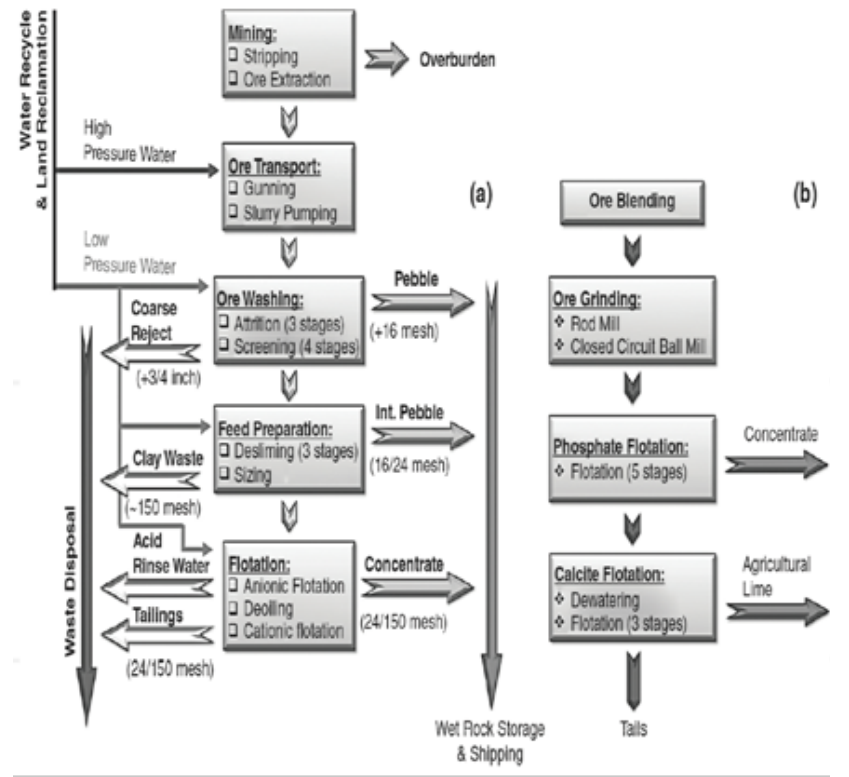

Figure I Mining and beneficiation of sedimentary (A) phosphate ore (B) Igneous phosphate ore ${ }^{51}$

\section{Association of toxic metals and radioactive elements in phosphate rock}

\section{Toxic metals in phosphate rock}

As iron and aluminum are essential for human existence, toxic heavy metals are among which are of non essential for human existence. Increased concern about the entry of the various metals in to human food chain has initiated the need to explore the connection between toxic metals and phosphate product in different parts of the world. ${ }^{22}$ Result indicated that Arsenic, Chromium, Lead, Mercury, Nickel, Vanadium and Cadmium, (Table 2), are frequently associated with Phosphate rock. It was further indicated that sedimentary deposits are richer in toxic metals than igneous deposits (Table 3).

Table 2 Average toxic heavy metal concentrations in phosphate rock deposits adapted from Kongshaug et al. ${ }^{22}$

\begin{tabular}{|c|c|c|c|c|c|c|c|}
\hline \multirow{2}{*}{ PR deposits } & \multicolumn{7}{|c|}{ Heavy metal concentration $\left(\mathrm{mgKg}^{-1}\right)$} \\
\hline & As & Cd & $\mathrm{Cr}$ & $\mathbf{P b}$ & $\mathbf{H g}$ & $\mathbf{N i}$ & $\mathbf{v}$ \\
\hline Russian (Kola) & I & 0.1 & 13 & 3 & 0.01 & 2 & 100 \\
\hline USA & 12 & 11 & 109 & 12 & 0.05 & 37 & 82 \\
\hline South Africa & 6 & 0.2 & 1 & 35 & 0.06 & 35 & 3 \\
\hline Morocco & 11 & 30 & 225 & 7 & 0.04 & 26 & 87 \\
\hline North Africa & 15 & 60 & 105 & 6 & 0.05 & 33 & 300 \\
\hline Middle East & 6 & 9 & 129 & 4 & 0.05 & 29 & 122 \\
\hline $\begin{array}{l}\text { Average } 91 \% \text { of } \mathrm{Pr} \\
\text { reserves }\end{array}$ & 11 & 25 & 199 & 10 & 0.05 & 29 & 88 \\
\hline P- $\mathrm{mg} / \mathrm{kg}$ & 71 & 165 & 1226 & 66 & 0.29 & 189 & 578 \\
\hline $\begin{array}{l}\text { g/ha/yr applied with20 } \\
\mathrm{kg}-\mathrm{p} / \mathrm{ha}\end{array}$ & I & 3.3 & 25 & 1 & 0.01 & 4 & 12 \\
\hline $\begin{array}{l}\text { Tolerance limit in soil, } \\
\mathrm{mg} / \mathrm{kg}\end{array}$ & 2 & 100 & 100 & 2 & 50 & 50 & 300 \\
\hline
\end{tabular}


Table 3 Average phosphorus and toxic heavy metal concentrations in rock phosphate from different origin (adapted from ${ }^{51,57,59}$ )

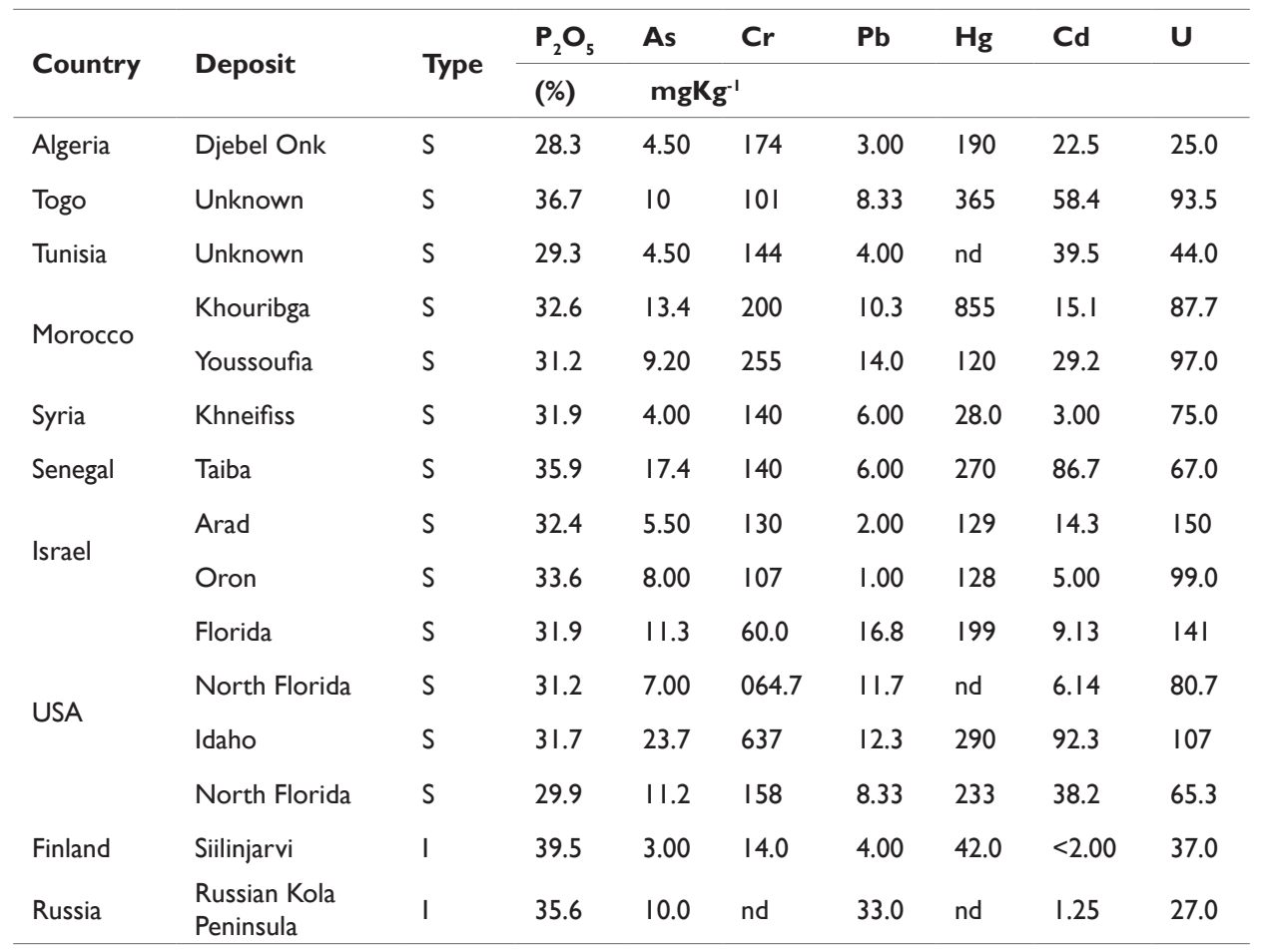

S. Sedimentary rock phosphate, I. Igneous phosphate, nd. no data.

\section{Radioactivity elements in phosphate rock}

The radioactivity of phosphate rock was probably first observed in 1908, when the British physicist R. Strutt found that samples of phosphorite were many times more radioactive than the average rocks of the Earth's crust. ${ }^{23}$ The dominant radioactivity detected in phosphate rocks are uranium, thorium and their decay products in equilibrium with their respective parent elements in the ore. ${ }^{24}$ The Uranium series includes ${ }^{238} \mathrm{U},{ }^{234} \mathrm{Th},{ }^{234} \mathrm{U}$; ${ }^{230} \mathrm{Th} ;{ }^{226} \mathrm{Ra},{ }^{222} \mathrm{Rn},{ }^{210} \mathrm{~Pb}$, ${ }^{210} \mathrm{Bi}$ and ${ }^{210} \mathrm{Po}$, Thorium series includes ${ }^{232} \mathrm{Th}$; ${ }^{228} \mathrm{Ra},{ }^{228} \mathrm{Ac} ;{ }^{228} \mathrm{Th}$, ${ }^{224} \mathrm{Ra},{ }^{220} \mathrm{Rn},{ }^{212} \mathrm{~Pb},{ }^{212} \mathrm{Bi}$. Of all the radionuclides in phosphate rock, ${ }^{226} \mathrm{Ra}$ is of particular interest because of its long half-life, radiotoxicity and its relative physical and biological mobility. The nuclide is of further importance as the parent nuclide of the gaseous ${ }^{222} \mathrm{Rn}$ which, along with its solid decay products, constitutes a significant source of radiation exposure. Concentrations of ${ }^{226} \mathrm{Ra}$ in phosphate rock are reported to vary, covering a range of $1-2 \mathrm{~Bq} / \mathrm{g} \cdot{ }^{25-29}$ Most of the ${ }^{226} \mathrm{Ra}$ in the ore ends up in the waste phosphogypsum during the production of phosphate fertilizers. The concentration of ${ }^{226} \mathrm{Ra}$ in these wastes is reported to be nearly $1 \mathrm{~Bq} / \mathrm{g}$. ${ }^{25,27}$

\section{Transfer pathways of toxic metals and radioactive elements}

There are a number of means by which the toxic metals and radioactive elements from the mining may be favorably transferred into the environment. The most common pathways are during the mining and beneficiation effects.

\section{Mining effect}

Land disturbance by phosphate mining activities would be expected to increase the concentrations and loads of many dissolved and suspended toxic metals and radioactive elements in the environment, including some that are particularly important for water quality and air pollution and human health.

The following major mining effects has been discussed,, 30

i. Erosion of soils and mine wastes into surface waters

ii. Impacts of tailings impoundments and heap leaching

iii. Acid mine drainage and contaminant leaching

iv. Acid mine water dewatering

\section{Beneficiation effect}

There are two types of phosphate processing: The wet processing and dry thermal processing. The wet processing, done with Sulfuric acid, is the most used method for more than $90 \%$ of the phosphate fertilizer production. The reaction of calcium phosphate with sulfuric acid leads to different products depending upon the relative amount of Sulfuric acid added to the phosphate ore (Figure 2): the first reaction used produce SSP; the second reaction used to produce WPA; the third reaction used to produces TSP; if phosphoric acid is neutralized by ammonia, the fourth reaction can lead to the production of MAP and DAP etc. Phosphogypsum is the byproduct in wet processing. Generally, 4-5 tons of phosphogypsum are produced per ton of phosphoric acid $\left(\mathrm{P}_{2} \mathrm{O}_{5}\right) \cdot{ }^{31}$

$$
\begin{aligned}
& \mathrm{Ca}_{3}\left(\mathrm{PO}_{4}\right)_{2}+2 \mathrm{H}_{2} \mathrm{SO}_{4} \rightarrow \mathrm{Ca}\left(\mathrm{H}_{2} \mathrm{PO}_{4}\right)_{2}+2 \mathrm{CaSO}_{4} \\
& \mathrm{Ca}_{3}\left(\mathrm{PO}_{4}\right)_{2}+3 \mathrm{H}_{2} \mathrm{SO}_{4} \rightarrow 2 \mathrm{H}_{3} \mathrm{PO}_{4}+3 \mathrm{CaSO}_{4} \\
& \mathrm{Ca}\left(\mathrm{PO}_{4}\right)_{2}+4 \mathrm{H}_{3} \mathrm{PO}_{4} \rightarrow 3 \mathrm{Ca}\left(\mathrm{H}_{2} \mathrm{PO}_{4}\right)_{2}
\end{aligned}
$$


$\mathrm{NH}_{3}+\mathrm{H}_{3} \mathrm{PO}_{4} \rightarrow \mathrm{NH}_{4} \mathrm{H}_{2} \mathrm{PO}_{4}$

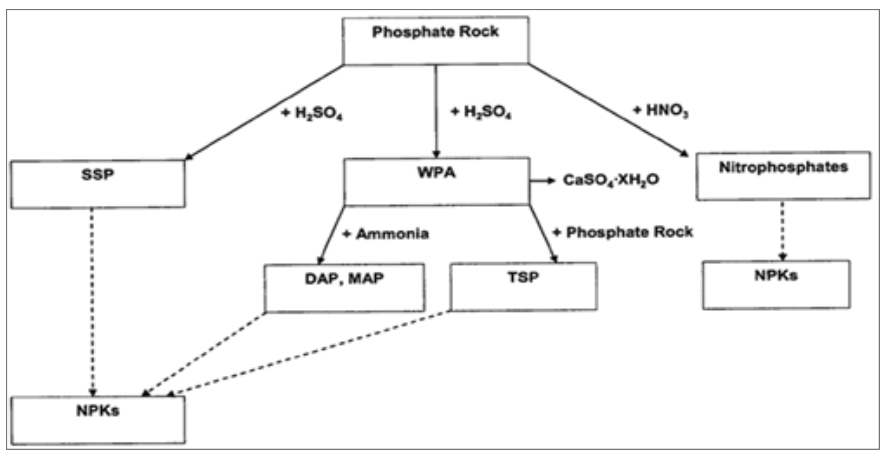

Figure 2 Relationship of Phosphate Rock and Phosphate Fertilizers: WPA. Wet Process Phosphoric Acid, SSP. Single Superphosphate, DAP. Diammonium Phosphate, MAP. Monoammonium Phosphate, TSP. Triple Superphosphate and NPKs. NPK-compounds. ${ }^{52,53}$

In the dry thermal process phosphorus vapour and carbon monoxide are produced after the phosphate ore is heated to $1500^{\circ} \mathrm{C}$ in an electric furnace. As a by-product a large amount of calcium silicate $\mathrm{CaSiO}_{3}$ slag is produced.

$$
\begin{aligned}
& \mathrm{Ca}_{3}\left(\mathrm{PO}_{4}\right)_{2}+3 \mathrm{SiO}_{2} \rightarrow 3 \mathrm{CaSiO}_{3}+\mathrm{P}_{2} \mathrm{O}_{5} \\
& \mathrm{P}_{2} \mathrm{O}_{5}+5 \mathrm{C} \rightarrow 5 \mathrm{CO}+2 \mathrm{P}
\end{aligned}
$$

In the thermal process the chemical reaction at high temperature produces elemental Phosphorus, which is relatively free of radioactivity. In the wet process method, ${ }^{226} \mathrm{Ra}$ is co-precipitated with the gypsum, while ${ }^{238} \mathrm{U}$ and ${ }^{232} \mathrm{Th}$ follow the Phosphorus into the phosphoric acid, which is then used to manufacture various fertilizer products. ${ }^{24}$ In general, about $80 \%$ of the ${ }^{226} \mathrm{Ra}, 30 \%$ of the ${ }^{232} \mathrm{Th}$ and $14 \%$ of the ${ }^{238} \mathrm{U}$ is left in the phosphogypsum. ${ }^{238} \mathrm{U}$ and ${ }^{232} \mathrm{Th}$ become enriched in the fertilizer to about $86 \%$ of their original value (Figure $3)$.

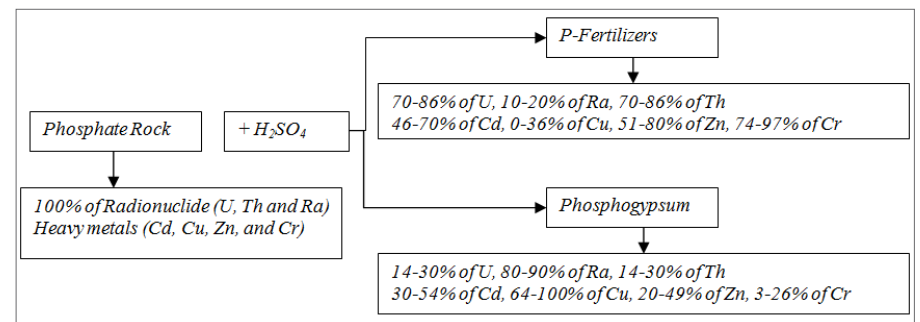

Figure 3 Transfer of most important radionuclides and heavy metals from rock phosphate to P-fertilizers and phosphogypsum during the production process, adapted from..$^{31,54-59}$

\section{Discussion}

\section{Impact of on water resources}

\section{Impact on the hydrology}

During mining and processing water is generally needed for:

i. Disintegration and slurrying of the ore at the pit, ii. Transportation of ore by slurry from pit to beneficiation plant, then through wet screening or classifying devices,

iii. Transportation of waste products to settling ponds or other waste disposal areas,

iv. Separation of phosphate from impurities in the flotation process, and

v. Drinking and sanitary supply for the plant area.

Several studies..$^{32-34}$ have documented the historical hydrological changes that had occurred at different location due to phosphate mining induced environmental impacts. The impacts of phosphatemining on surface and groundwater resources in west central Florida, USA was the subject of a study conducted by Lewelling \& Wylie ${ }^{32}$ The background hydrologic characteristics and water quality of three unmined basins in the area were compared to mined and phosphatemined and reclaimed basins. Result indicated that the hydrologic effects of mined and reclaimed area vary with the type of fill material used during reclamation. Peak runoff rates from the mined basins generally were higher than those from the unmined basins during intense rainfall; Runoff responds more slowly to rainfall in the mined basins than in the unmined basins because of undeveloped drainage systems in the mined basins. The depth to the water table in the surficial aquifer in the mined basins generally was much greater than that in the unmined basins. Concentrations of dissolved solids, iron, sulfate, manganese, and lead exceeded regulatory standards at various reclaimed basins. Reclaimed basins backfilled with clay commonly are rich in radiochemical constituents associated with phosphate ore, and streams draining these basins sometimes contain water with elevated concentrations of these constituents.

A comparison study of hydrologic conditions in Osceola National Forest, Florida, USA with those in the same region Hamilton County, where phosphate mining and ore processing have been ongoing since $1965,{ }^{33}$ showed that the potential impact of Phosphate mining in the forest would be expected to produce effects similar to those observed in the present day Hamilton County mining and beneficiation operation. The flow characteristics of the streams draining of the forest would be changed due to shifting of basin divides and an interbasin transfer of water. Average flow would be increased about 40 percent by phosphate industry releases consisting largely of water added to the hydraulic system of the phosphate mining complex from pumpage of the Floridan aquifer. In practice, the effect would be most notable during low-flow periods and at those particular times when releases from the hydraulic system are withheld. The effluentreceiving stream(s) would have average concentrations of dissolved solids, sulfate, phosphorous, nitrogen, and fluoride that are higher than under natural conditions. Suspended sediment concentrations would increase in all the streams draining the forest because of the landclearing and excavation activities and the draining of swampland.

The main objective of the investigation by $A^{3 r n o w}{ }^{35}$ was to determine the influnce of phosphate mining on the ground water of Anguar, Palau Islands. The removal of phosphate ores by mechanized methods resulted in a deep pits extending below the water table. Another study by Wang et al., ${ }^{36}$ indicated that effect of phosphate mining activities in the area generally reduced runoff coefficient and runoff peak. The impact of phosphate mining on offshore (submarine) phosphorite minerals such as glauconite mining activities differs according to the specific locality and the effects of the mining 
operation on intertidal, sub tidal or deep-sea marine environments. Many offshore mining operations are vulnerable to inclement weather conditions that pose added risks of fuel and material spills and loss of human life.

\section{Impacts on water quality}

Water quality control is not very easy in the fatty acid or anionic flotation process, nor in wet sizing transportation of the clay-free feed. ${ }^{33}$ Clear water is required to transport the "deslimed" wet-sized or washer product to further beneficiation circuits. Swamp waters that contain inorganic acids cause problems. Turbid water is detrimental to the separation processes. Slightly alkaline water is preferred to decrease reagent costs. The amine or cationic flotation process is sensitive to water quality. In this process, deep well water is generally used because it possesses the desired qualities of low suspended solids content and a constant $\mathrm{pH}^{33,36}$ Several studies have discussed the impact of phosphate mining on water quality. Most of the concerns are associated with, Acidic process water. ${ }^{2,37}$ Radionuclides, ${ }^{38}$ Phosphate runoff, ${ }^{39,40}$ and Toxic fluoride and heavy metals in runoff. ${ }^{41,42}$

The primary purpose of the investigation by Miller \& Sutcliffe ${ }^{37}$ was to document the effect of three phosphate industries on the groundwater quality in central Florida, USA. Geologic, topographic, and hydrologic environments were examined in relation to phosphate industry operations. Emphasis was on the effects from gypsum stacks and associated ponds with some additional effort on slime ponds. Test holes were drilled around the ponds and in the area of the ponds at multiple depths to define the extent and magnitude of movement of any contaminants in to surface and intermediate aquifer. The result of the investigation indicated that the chemistry of the water from the mining and beneficiation operations and the native ground water was different. The highly acidic mine water has a solute constituents of about $28,000 \mathrm{mg} / \mathrm{L}$, a pH of 1.4 to 1.8 units, and contains sodium, phosphate, fluosilicate, hydrogen, and sulfate ions as major constituents. On the others hand the native ground water has a dissolved-solids concentration of less than 500 milligrams per liter and is calcium bicarbonate water with a $\mathrm{pH}$ near 7.0units. Sodium and sulfate ions are the most mobile of the contaminant-source constituents in process water. Migration of radionuclides, fluosilicates, phosphates, and trace metals is largely controlled by the degree of acid neutralization as the result of reaction with aquifer materials, and is generally restricted to areas immediately adjacent to the source. Iodide, bromide, and ammonium are useful as tracers near gypsum stacks. Phosphate slimes from mining and beneficiation operations were found to contain phosphorus, trace metals, and radiochemicals. These substances were associated with solid materials and were effectively retained by the slime pond.

Recent assessment by Beavers et al., ${ }^{2}$ on the phosphate mining activities in Florida, USA, observed that intentional or accidental discharges of process water in to the local water channels risks the water quality of the surrounding surface water. By virtue of its chemical behavior, apatite is generally associated with fluoride, which is a potential contaminant. ${ }^{43}$ There are several studies specifically studied the water quality impacts of fluoride toxicity from phosphate mining. ${ }^{42}$ studied the fluoride in water in the Alafia and Peace River basin Florida, USA, and found that waste water from phosphate chemical plants in the tributary headwater areas contributes fluoride and other waste products to the Alafia and Peace rivers. The fluoride concentration of the Alafia River at Lithia, Florida, ranged from 3.2 to 30ppm (parts per million) and the Peace River at Arcadia, Florida, ranged from 0.6 to $2.2 \mathrm{ppm}$ in samples of water collected. The natural fluoride concentration in streams in the Alafia and Peace River basins generally ranged from 0.2 to $0.4 \mathrm{ppm}$ as determined from analysis of water from streams away from the active areas of mining and processing of fluoride bearing phosphate minerals. The drinking water permissible limit of fluoride is $1.5 \mathrm{mg} / \mathrm{litre}^{44}$

The un-restored post-phosphate mined lands in Lake Fuxian watershed, Yunnan Province, china are large scale. The main objective of the study by Feng ${ }^{40}$ was to investigated the amounts of pollutants releasing from phosphate mined lands and transporting by runoffs. The releasing and transporting amounts of pollutants were calculated from column leaching studies and acreages of exposed phosphrite layers and overburdens. The results showed that the amounts of fluoride and phosphorus releasing were $60.65 \mathrm{t} / \mathrm{a}$, and $27.34 \mathrm{t} / \mathrm{a}$, respectively, and the amounts of fluoride and phosphorus transported by surface runoffs were $22.58 \mathrm{t} / \mathrm{a}$, and $7.27 \mathrm{t} / \mathrm{a}$, respectively. ${ }^{39}$ when studied the water quality of Udaisagar lake, downstream of a phosphate mining, in Rajasthan, India, has found elevated concentration of phosphate (186 in surface water and $236 \mathrm{mg} / \mathrm{l}$ in sub surface) and conclude that the enormous and wide-spread growth of algal bloom in lake water and Ahar river and occasional fish mortality are indications of eutrophic conditions prevailing in the lake.

Release of toxic trace elements from mining activities and accumulation in the food chain has result in the adverse biological effect on local horses and sheep southeastern Idaho, USA. After a series of studies by Hamilton \& Buhl ${ }^{41}$ it was found that selenium concentrations from the phosphate mining area of southeastern Idaho, USA, were sufficiently elevated in several ecosystem components to cause adverse effects to aquatic resources in the Blackfoot River watershed..$^{38}$ investigated Uranium contents in Waste Water drains channel. The results (Table 4) show that average uranium contents $\left(\mathrm{mgm}^{-3}\right)$ in a three-month period are appreciable in the waste water channel.

Table 4 Average Uranium concentration $\left(\mathrm{mg} / \mathrm{m}^{3}\right)$ of the waste water drains of various units of the investigated phosphoric acid and fertilizer Produced in the factory in three months period, after ${ }^{38}$

\begin{tabular}{lll}
\hline Material & $\begin{array}{l}\text { Fertilizer } \\
\text { produced in the } \\
\text { factory }\end{array}$ & $\begin{array}{l}\text { In waste water } \\
\text { drain }\end{array}$ \\
\hline $\mathrm{H}_{3} \mathrm{PO}_{4}$ Unit I (54\%) $\mathrm{P}_{2} \mathrm{O}_{5}$ & $18.8 \mathrm{I}(+/$ ) 0.94 & $35.69(+/-) \mathrm{I} 3.86$ \\
$\mathrm{H}_{3} \mathrm{PO}_{4}$ Unit II (28\%) $\mathrm{P}_{2} \mathrm{O}_{5}$ & $40.19(+/-) 3.40$ & $20.75(+/-) 5.73$ \\
$\mathrm{NPK}$ process (15\%) $\mathrm{P}_{2} \mathrm{O}_{5}$ & $25.28(+/-) 2.09$ & $23.94(+/-) 1.1 \mathrm{I}$ \\
DAP process (I5\%) $\mathrm{P}_{2} \mathrm{O}_{5}$ & $51.76(+/-) 4.37$ & $58.26(+/-) 25.43$ \\
$\begin{array}{l}\text { Sea Discharged Joint } \\
\text { Channel }\end{array}$ & & $34.01(+/-) 12.60$ \\
\hline
\end{tabular}

\section{Impacts on air quality}

Air quality tends to be a serious problem of the mining industries. Dust is a common problem throughout all mining activities, ${ }^{9}$ the most important air quality problems related to phosphate mining activities are associated with Fluoride emissions and Radon gas emission. ${ }^{8}$ Several studies can be found specifically concerned on the influence of phosphate mining on the air quality. The main objective of the study by Raja et al. ${ }^{45}$ was to investigate the chemical and mineralogy 
characteristics of dust collected near the phosphate mining basin of Gafsa, Tunisia. It was found that heavy metals pollution increased by the proximity to the mining area; samples were enriched predominantly in $\mathrm{SiO}_{2}, \mathrm{CaO}$ and $\mathrm{P}_{2} \mathrm{O}_{5}$ which were detected only at mining area.

\section{Impact on human health}

From human healthy perspective at least 57 of the trace elements in phosphate rock have been reported to possess toxicity to varying degrees, and $\mathrm{Be}, \mathrm{As}, \mathrm{Cd}, \mathrm{Hg}, \mathrm{Tl}$, and $\mathrm{Ra}$ are generally designated as extremely toxic. ${ }^{46}$ Using information on major pollutants and the works of ${ }^{46-49}$ has classified the toxicity of phosphate products according to their risk to human health (Table 5).$^{50}$ was to measure the doses arising from effluent discharges from the phosphate rock processing plant of SICNG (Societe Industries Chimiclues du Nord de la Grece),Thessaloniki, Northern Greece. The major airborne emissions occur in the form of fine rock dust from drying and grinding operations of phosphate rock. Collective dose commitments resulting from atmospheric releases of ${ }^{238} \mathrm{U}$ and ${ }^{226} \mathrm{Ra}$ from phosphate rock processing plants were estimated for the case of inhalation during the passage of radioactive cloud, (Table 6). Lung tissue is more suffered from ${ }^{238} \mathrm{U}$ and ${ }^{226} \mathrm{Ra}$ inhaled during the cloud passage as compared with the other organs or tissues.

Table 5 Degree of toxicity of elements in phosphate rock ${ }^{46}$

\begin{tabular}{ll}
\hline $\begin{array}{l}\text { Associated elements found in phosphate } \\
\text { rock }\end{array}$ & Degree of toxicity \\
\hline $\mathrm{Be}, \mathrm{As}, \mathrm{Cd}, \mathrm{Hg}, \mathrm{Tl}, \mathrm{Ra}$ & Extreme \\
$\mathrm{F}, \mathrm{Cl}(\mathrm{Cl} 2), \mathrm{Cr}(\mathrm{CrlV}, \mathrm{CrVl}), \mathrm{Ba}, \mathrm{Gd}, \mathrm{Yb}, \mathrm{Pb}$ & High \\
$\mathrm{Li}, \mathrm{Ni}, \mathrm{Cu}, \mathrm{Ga}, \mathrm{Sn}, \mathrm{Sb}, \mathrm{Te}, \mathrm{La}, \mathrm{Ce}, \mathrm{Pr}, \mathrm{Nd}, \mathrm{Sm}, \mathrm{Tb}, \mathrm{Ho}$, & Moderate \\
$\mathrm{Bi}, \mathrm{Th}, \mathrm{U}$ & \\
$\mathrm{Ca}, \mathrm{V}, \mathrm{Mn}, \mathrm{Fe}, \mathrm{Zn}, \mathrm{Ge}, \mathrm{Mo}, \mathrm{Lu}$ & Low \\
$\mathrm{Mg}, \mathrm{S}, \mathrm{Ca}, \mathrm{Sc}, \mathrm{Co}, \mathrm{Se}, \mathrm{Sr}, \mathrm{Y}, \mathrm{Zr}, \mathrm{Nb}, \mathrm{Ag}, \mathrm{In}, \mathrm{I}, \mathrm{Dy}, \mathrm{Eu}, \mathrm{Er}$, & Negligible \\
$\mathrm{Tm}, \mathrm{Hf}, \mathrm{Au}$ & \\
\hline
\end{tabular}

Table 6 Estimated collective dose commitments (man Gy t-I) From atmospheric releas of $238 \mathrm{U}$ and $226 \mathrm{Ra}$ from phosphate rock processing plant SICNG, Thessaloniki, Northern Greece, after ${ }^{50}$

\begin{tabular}{lll}
\hline Organ or tissue & ${ }^{238} \mathbf{U} \times 10^{-9}$ & ${ }^{226} \mathrm{Rax} 10^{-9}$ \\
\hline Lungs & 1.957 & 0.152 \\
Bone surfaces & 0.0214 & 0.065 \\
Red bone marrow & 0.0014 & 0.0057 \\
Liver & 0.0000356 & 0.00076 \\
Kidneys & 0.0089 & 0.00076 \\
Spleen & 0,0000356 & 0.00076 \\
G.l. track & 0.000249 & 0.00114 \\
Other soft tissues & 0.0000356 & 0.00076
\end{tabular}

\section{Conclusion and recommendation}

\section{Conclusion}

Although the subject of mining and its impacts are very wide to cover in this review, concerns about the impact of phosphate mining with emphasis on water resources, air quality, and human health were accessed. Several studies have documented the historical hydrological changes that had occurred at different location due to phosphate mining induced environmental impacts. According to these studies the main impact of phosphate mining on water resources were impacts on the hydrology by phosphate industry water usage and landscape changes, and impacts on water quality by discharges of industry wastewater into the waterways. Several studies have also discussed on the impact of phosphate mining on water quality, most of the concerns were associated with; acidic mine water drainage, release of potentially toxic metals, release radioactive elements, and phosphate and nutrients in runoff. Dust was a regular problem to all type of mining; the most important air quality problems associated with phosphate mining activities are associated with, fluoride emissions, radon gas emission. For human healthy, toxic metals and radioactive elements of significant phosphate products were $\mathrm{Pb}, \mathrm{Cd}, \mathrm{Hg}, \mathrm{Cr}, \mathrm{As}$, $\mathrm{U}$ and Ra.

\section{Recommendation}

Scientific research on mine water drainage and water resource protection relationship could be the most important steps in water resources and environmental management associated with phosphate mining. The success could be achieved through

i. Construction of water resources protection facilities to control the source of pollution and reduce the discharge of pollutants from the mine

ii. Construction effective mine/acid water drainage system control to protect mining induced groundwater-surface water contaminations

iii. Establish automatic real-time hydrology and water quality monitoring strategy

iv. Develop the opportunities to re-use of process water.

\section{Funding}

This research has been supported by Non-profit Industry Financial Program of Ministry of Water Resources of China (No. 201301066), the National Natural Science Foundation of China (40701024, 41101511, 51409152), and Hubei Provincial Collaborative Innovation Center for Water Security

\section{Acknowledgements}

The authors are gratefully acknowledging the Government of the Republic of China through Chinese Government Scholarship (CSC) for the full scholarship grant to finish this research.

\section{Conflicts of interest}

The author declares no conflict of interest.

\section{References}

1. McKelvey VE. Phosphate deposits. US Govt Print Off; 1967.

2. Beavers $\mathrm{C}$, Ellis R, Hanlon CDE, et al. An overview of phosphate mining and reclamation in Florida. Citeseer. 2013;1-33.

3. Szilas C. The Tanzanian Minjingu phosphate rock. Possibilities and limitations for direct application. Center for Skov, Landskab og Planlægning/Københavns Universitet. 2002;1-187.

4. Menzel RG. Uranium, radium, and thorium content in phosphate rocks and their possible radiation hazard. Dept of Agriculture Beltsville Md. 1968. 
5. Fávaro D. Natural radioactivity in phosphate rock, phosphogypsum and phosphate fertilizers in Brazil. Journal of Radioanalytical and Nuclear Chemistry. 2005;264(2):445-448.

6. Mazzilli B, Palmiro V, Saueia C, et al. Radiochemical characterization of Brazilian phosphogypsum. Journal of Environmental Radioactivity. 2000;49(1):113-122.

7. Slack A. Fertilizer products The Fertilizer Handbook. The Fertilizer Institute, Washington, DC. 1972;47-65.

8. Association IFI. Environmental aspects of phosphate and potash mining. UNEP. 2001;1-68.

9. Chernaik M. Guidebook for evaluating mining project EIAs. Environmental Law Alliance Worldwide 8. 2010;1-122.

10. Okoli C, Schabram K. A guide to conducting a systematic literature review of information systems research. Working Papers on Information Systems. 2010;1-51.

11. Van Straaten P. Rocks for crops: agrominerals of sub-Saharan Africa. Citeseer. 2002;1-348.

12. Van Straaten P. Agrogeology: the use of rocks for crops. Enviroquest \& Peter van Straaten. 2007.

13. CLARKE R, Youn E. Geochemistry of uranium in apatite and phosphorites. US Geol Survey Prof Paper. 1958;45-90.

14. Deer WA, Howie RA, Zussman J. Rock-forming Minerals: Non-silicates. Longman.1962.

15. Palache C, Berman H, Frondel C. The System of Mineralogy. In: Wiley J, editor. New-York. 1951;1087-1089.

16. Mathew M, Takagi S. Structures of biological minerals in dental research. Journal of research of the National Institute of Standards and Technolog. 2001;106(6):1035.

17. Sudarsanan K, Mackie P, Young R. Comparison of synthetic and mineral fluorapatite, $\mathrm{Ca}_{5}\left(\mathrm{PO}_{4}\right) 3 \mathrm{~F}$, in crystallographic detail. Materials Research Bulletin. 1972;7(11):1331-1337.

18. Dudka S, Adriano DC. Environmental impacts of metal ore mining and processing: a review. Journal of environmental quality. 1997;26(3):590-602.

19. Kent JA. Riegel's handbook of industrial chemistry. Springer Science \& Business Media; 2012.

20. Rule A, Kirby D, Dahlin D. Recent advances in beneficiation of western phosphates. Mining Eng. 1978;30:37-40.

21. Van Kauwenbergh SJ. World phosphate rock reserves and resources. IFDC Muscle Shoals. 2010;1-60.

22. Kongshaug G, Bockman O, Kaarstad O, et al. Inputs of trace elements to soils and plants Chemical Climatology and Geomedical Problems. Ed $J$ Lag. 2012;85-216.

23. Strutt R. On the accumulation of helium in geological time. Proceedings of the Royal Society of London Series A, Containing Papers of a Mathematical and Physical Character. 1908;81:272-277.

24. Scholten L, Van der Steen J. Approaches for regulating management of large volumes of waste containing natural radionuclides in enhanced concentrations. Directorate-General Environment, Nuclear Safety and Civil Protection. 1996;1-11.

25. Lardinoye M, Weterings K, Van De Berg W. Unexpected 226Ra build-up in wet-process phosphoric-acid plants. Health physics. 1982;42:503-514.

26. Mills W, Guimond R, Windham S. Radiation exposures in the Florida phosphate industry Radiation Protection as an Example of Action against
Modern Hazards. Proc 4th Int Congr of the International Radiation Protection Association Paris. 1977;3:1049-1052.

27. Paul A, Londhe V, Pillai K. Radium-228 and Radium-226 levels in a river environment and its modification by human activities. Natural radiation environment. 1980;1633-1654.

28. Pfister H, Philipp G, Pauly H. Population dose from natural radionuclides in phosphate fertilizers. Radiation and Environmental Biophysics. 1976;13:247-261.

29. Philipp G, Pfister H, Pauly H. Occupational dose from natural radionuclides in phosphate fertilizers. Radiation and Environmental Biophysics. 1979;16(2):143-156.

30. Council NR. Uranium mining in Virginia: scientific, technical, environmental, human health and safety, and regulatory aspects of uranium mining and processing in Virginia. National Academies Press. 2012.

31. IAEA. Extent of environmental contamination by naturally occurring radioactive material (NORM) and technological options for mitigation. Internat Atomic Energy Agency. 2003;208.

32. Lewelling B, Wylie R. Hydrology and water quality of unmined and reclaimed basins in phosphate-mining areas, west-central Florida. US Geological Survey. 1993;1-102.

33. Miller JA, Hughes G, Hull R, et al. Impact of potential phosphate mining on the hydrology of Osceola National Forest, Florida. US Geological Survey, Water Resources Division. 1978;1-174.

34. PBSJ. Peace River Cumulative. Impacts Study Summary. 2007;107.

35. Arnow T. Effects of phosphate mining on the ground water of Anguar, Palau Islands. Trust Territory of the Pacific Islands. USGPO. 1961;1-54.

36. Wang K, Lin Z, Zhang R. Impact of phosphate mining and separation of mined materials on the hydrology and water environment of the Huangbai River basin. China Science of the Total Environment. 2016;543:347-356.

37. Miller RL, Sutcliffe H. Effects of three phosphate industrial sites on ground-water quality in central Florida, 1979 to 1980. US Department of the Interior, US Geological Survey. 1984;1-194.

38. Uyanik A, Tinkiliç N, Odabașoğlu M, et al. Spectrophotometric determination of uranium in waste water of phosphoric acid and fertilizer manufacturing process. Turkish Journal of Chemistry. 1999;23:275-284.

39. Das B. Environmental pollution of Udaisagar lake and impact of phosphate mine, Udaipur, Rajasthan. India Environmental Geology. 1999;38(3):244-248.

40. Feng M, Pan J, Ke F, et al. Water pollution of post-mined lands in Lake Fuxian watershed in Yunnan Province. Journal of Lake Sciences. 2008;6:014.

41. Hamilton SJ, Buhl K. Selenium in water, sediment, plants, invertebrates, and fish in the Blackfoot. River Drainage Water, Air, \& Soil Pollution. 2004;159(1):3-34.

42. Toler L. Fluoride in water in the Alafia and Peace River basins Florida. Florida Geological Survey Report of Investigations. 1967;46:1-54.

43. Manning DA. Phosphate minerals, environmental pollution and sustainable agriculture. Elements. 2008;4(2):105-108.

44. Fawell JK, Bailey K. Fluoride in drinking-water. World Health Organization; 2006.

45. Raja M, Dalila T, Ammar BB. Chemical and mineralogy characteristics of dust collected near the phosphate mining Basin of Gafsa (SouthWestern of Tunisia). Journal of Environmental \& Analytical Toxicology. 2014;4:1-6. 
46. Chen M, Graedel TE. The potential for mining trace elements from phosphate rock. Journal of Cleaner Production. 2015;91:337-346.

47. Butterman W, Reese Jr R. Mineral Commodity Profiles Rubidium. US Geological Survey. 2003;1-11.

48. Graedel T. On the future availability of the energy metals. Annual Review of Materials Research. 2011;41:323-335.

49. Jandova J, Dvořák P, Formánek J, et al. Recovery of rubidium and potassium alums from lithium-bearing minerals. Hydrometallurgy. 2012;119:73-76

50. Papastefanou C. Radiological impact from atmospheric releases of $238 \mathrm{U}$ and $226 \mathrm{Ra}$ from phosphate rock processing plants. Journal of environmental Radioactivity. 2001;54(1):75-83.

51. Kharikov A, Smetana V. Heavy metals and radioactivity in phosphate fertilizers. Short term detrimental effects. 2012.

52. Moisset J. Radium removal from phosphogypsum. Phosphogypsum. $1980 ; 442-457$.

53. Van Kauwenbergh SJ. Fertilizer raw material resources of Africa. IFDC. 2006;1-454

54. El-Mrabet R, Abril J-M, Periáñez R, et al. Phosphogypsum amendment effect on radionuclide content in drainage water and marsh soils from southwestern Spain. Journal of environmental quality. 2003;32(4):1262-1268.

55. Garcia-Leon M, Martinez-Aguirre A, Perianez R, et al. Levels and behavior of natural radioactivity in the vicinity of phosphate fertilizer plants. Journal of radio analytical and nuclear chemistry. 1995;197(1):173-184.

56. Rutherford P, Dudas M, Samek R. Environmental impacts of phosphogypsum. Science of the Total Environment. 1994;149(1-2):1-38.

57. Kratz S, Schnug E. Schwermetalle in P-Düngern Landbauforschung Völkenrode. Special. 2005;286:37-45.

58. UNIDO, IFDC. Fertilizer Manual. The Netherlands: United Nations Industrial Development Organization (UNIDO) and International Fertilizer Development Center (IFDC). 1998.

59. Van Kauwenbergh SJ. Cadmium and other minor elements in world resources of phosphate rock. Proceedings-Fertiliser Society (United Kingdom). 1977. 